ancient classical writers. His health was not robust, for he laboured under a difficulty of respiration all his life.

He conducted for many years a large practice in private; his clinical methods were remarkable for a thoroughness in what might be termed minutiae; he paid much attention to errors of refraction at a time when small errors where not held to be of such outstanding importance as they are to-day ; as a clinician, he was a past master, and his opinion was much in demand in consultation amongst his brothers in the ophthalmic fraternity.

On his retirement from University College Hospital he was elected Emeritus Professor of Ophthalmology.

Tweedy married in 1885 the daughter of Richard Hilhouse, of Finsbury Place, and had three children, two sons and a daughter. To Lady Tweedy and her family we wish to express our sincere sympathy.

\title{
ARTHUR CHARLES ROPER
}

ARthur Charles Roper, whose death took place at his residence at Exeter on January 11, came of an old West Country stock. His father, Mr. C. H. Roper, was a leading surgeon in Exeter, and served the office of Sheriff of the City, while his grandfather, Mr. W. Kennaway, was Mayor of Exeter in 1830 and 1836. Roper was born in 1858, and was educated at the Old Mount Radford School and St. Bartholomew's Hospital ; he qualified M.R.C.S.Eng. in 1880, and took the L.R.C.P.Edin. and L.M. in 1881, proceeding in 1890 to the F.R.C.S.Edin. For more than 40 years he had practised in his native city, and he occupied a leading place, not only in the city, but also in the County of Devon. Roper was connected with the Royal Devon and Exeter Hospital for 25 years and on retirement was elected Consulting Surgeon. A few years ago, he took a leading part in organizing an appeal by which more than $£ 6,000$ was subscribed for the building of new wards for children, and one of the new wards was named after him. His connexion with the West of England Eye Infirmary began in 1881 and as an ophthalmic surgeon, he was one of the best known men in the West of England. His other appointments included those of Consulting Surgeon to the Exeter Dispensary, the Exeter Hospital, Exeter Lying-in Charity and the Sidmouth Cottage Hospital, and he was Oculist to the Western Counties Institute for Mental Defectives and to the West of England Blind Institute. He was President of the South-West of England Ophthalmological Society in 1923.

Roper was elected Mayor of Exeter in 1920 and became J.P. in 1922. He took an active part in the proceedings of the British 
Medical Association in Exeter, and at the time of his death he was Chairman of the Devon Local Medical Committee and a member of the Devon Panel Committee. In The British Journal of OPHTHALMOLOGY for 1917 he wrote on prolapse of the iris in simple extraction of cataract, with an analysis of 300 cases of extraction; in the Lancet for 1922 he published a report on the results in 489 cases of extraction, while he contributed to the same Journal in 1888 a paper on the importance of the early treatment of squint.

In addition to his professional interests, he was a good athlete. $\mathrm{He}$ was for some years Captain of the Exeter Cricket Club, and a keen golfer and croquet player. Apart from out-door amusements his rhief hobby was music; for many years he was a member of the cathedral voluntary choir, of which he was, at the time of his death, joint honorary secretary; in younger days, he was much in demand at local concerts on account of his fine voice, and he took a prominent part in the foundation of the Exeter Dramatic Society. Mr. Roper is survived by a widow and four children, one of his sons being Physician to the Royal Devon and Exeter Hospital; much sympathy will be felt for them in their loss.

\section{NOTES}

WE greatly regret to record the death of Deaths Mr. T. BRITTIN ARCHER, Consulting Surgeon, and ex-Chairman of the Committee of Management of the Central London Ophthalmic Hospital. We hope to publish an obituary notice in our next number.

Ophthalmology in Brazil has suffered a severe loss in the death of PROFESSOR HILARIO DE GOUVÊA which occurred on October 25,1923 . He had reached the great age of 89 , having taken his degree as far back as 1866 with a thesis on glaucoma. He was chosen to occupy the Chair of Ophthalmology in the fáculty of Medicine in Rio de Janeiro when this post was first created, but for political reasons, he had to leave Brazil and live abroad for some years and it was not until 1899 that he was able to return. He contributed numerous articles to "Brazil Medico," and among his more important works may be mentioned the following: "Glaucoma," "Hemeralopia and Xerophthalmia through Defects of Nutrition," "Quinine Amaurosis," "Ocular Manifestations of Epilepsy" and "Medical Ethics in Brazil." $\mathrm{He}$ represented Brazil at many International Medical Congresses, at London, in 1881; at Berlin, in 1888 ; at Rome, in 1894, and at Paris in 1900. 